\title{
Association of genotypes by polymorphic variant C-108T of PON1 gene with the risk of developing breast cancer and hypertensive disease in women
}

\author{
L. Ye. Fishchuk
}

State Institute of Genetic and Regenerative Medicine, National Academy of Medical Sciences of Ukraine 67, Vyshgorods'ka Str., Kyiv, Ukraine, 04114

medgen@ukr.net

\begin{abstract}
Aim. To analyze the effect of the polymorphic variant C-108T of PON1 gene on the risk of developing breast cancer $(B C)$ and hypertensive disease (HD) in women. Methods. 130 women with non-complicated HD of degree II and 131 women with BC of I and II stages without cardiovascular complications were enrolled in the study. The control group was composed of 102 women without cardiovascular and oncological pathologies. Molecular-genetic analysis was performed on DNA isolated from the samples of peripheral blood. Genotyping of polymorphic variant C-108T of PON1 gene was carried out with the use of PCR-RFLP method. Results. It has been revealed that the presence of -108CC genotype of PON1 gene in women elevates the risk of HD development in more than 1.5 times. As for women over 54, the presence of -108CC genotype of PON1 gene is associated with a decreased risk of BC by almost 4 times and, in contrary, the presence of -108CT genotype of PON1 gene is associated with an increased risk of BC by more than 3 times. Conclusions. Polymorphic variant C-108T of PON1 gene may be considered as possible prognostic marker of $B C$ and $H D$ development in women.
\end{abstract}

Keywords: gene, PON1, breast cancer, hypertensive disease.

Introduction. According to the State Statistics Committee and the National Cancer Registry of Ukraine the cardiovascular pathology and oncological neoplasms are the main causes of mortality for women. The hypertensive disease (HD) ranks number one in the general structure of the cardiovascular pathology, and the breast cancer (BC) keeps the key place in the structure of the oncological neoplasms among the female population of Ukraine.

Some works demonstrated that HD is associated with the increased risk of developing the oncological pathology, BC, in particular [1]. On the other hand, it was determined that the antihypertensive therapy affects the risk of developing $\mathrm{BC}$ and influences the survival in patients with this pathology [2]. These data allow the assumption that $\mathrm{HD}$ and $\mathrm{BC}$ are interrelated, i. e. their development may be caused by similar pathological mechanisms. One of them can be the accumulation of free radicals and their reactive metabolites at the oxidative stress. One of important factors, promoting the forma-

(C) Institute of Molecular Biology and Genetics, NAS of Ukraine, 2014 tion of oxidative stress, is a decrease in the activity of paraoxonase 1 (PON1), an enzyme, involved in the metabolism of the oxygenated forms of lipids.

PON1 is the calcium-dependent hydrolase with broad substrate specificity, which is synthesized in the liver and secreted into the plasma, where it binds to the complex of high-density lipoproteins. It is known that PON1 (through the hydrolysis of the oxygenated phospholipids of the cellular membranes) prevents the oxydic modification of low-density lipoproteins, decreases the peroxides formation, and inhibits the cytokines production and the monocytes adhesion to the endothelial surface. The protective role of PON1 consists also in its participation in the metabolism of homocysteine-thiolactone, a metabolite of homocysteine, which is cytotoxic for the organism [3-5]. The genetic polymorphism in PON1 gene, coding PON1, is the main determinant of interindividual variability of the enzyme activity. PON1 is localized on the long arm of the chromosome 7q21.3. Among five polymorphic variants in the promoter part of the gene, the replacement of C-108T (some- 
Table 1

The distribution of the main study groups depending on age

\begin{tabular}{ccc}
\hline \multicolumn{3}{c}{ 18-35 years } \\
\hline BC & 53 & Average age, years \\
HD & 22 & $30.6 \pm 0.54$ \\
Control & $33.23 \pm 0.64$ \\
& $36-54$ years & $29.24 \pm 0.7$ \\
BC & 52 & $46.39 \pm 0.7$ \\
HD & 70 & $47.04 \pm 0.64$ \\
Control & 23 & $45.87 \pm 1.21$ \\
& over 54 years & \\
BC & 26 & $62.58 \pm 1.32$ \\
HD & 38 & $61.42 \pm 1.01$ \\
Control & 46 & $62.22 \pm 1.0$ \\
\hline
\end{tabular}

times C-107T, rs705379) has the highest impact on the PON1 activity in the plasma. In particular, it was demonstrated to be approximately twice higher for the people with the genotype $-108 \mathrm{CC}$ compared to the carriers of the genotype -108TT [3].

Up to date the associations of the polymorphic variant $\mathrm{C}-108 \mathrm{~T}$ of PON1 gene with the risks of cardiovascular diseases and oncological neoplasms have been studied [6-8], but not in Ukraine. Therefore, the purpose of our study was to analyze the effect of the polymorphic variant $\mathrm{C}-108 \mathrm{~T}$ of $P O N 1$ gene on the risk of developing $\mathrm{BC}$ and $\mathrm{HD}$ in women.

Materials and methods. The study involved 130 women with the diagnosis of non-complicated HD of degree II (group HD, average age $-48.57 \pm 0.1$ ) and 131 women with the diagnosis of BC of stages I and II without cardiovascular complications (group BC, average age $-43.21 \pm 1.14$ ). The control group included 102 women without cardiovascular and oncological pathologies (control, average age $-47.86 \pm 1.54$ ). Later the groups of women with $\mathrm{BC}$ and HD were divided into three age subgroups: from 18 to 35 years (18-35, young women), from 36 to 54 years (36-54, middle-aged women) and older than 54 years (over 54 , older age subgroup). The control group was divided likewise (Table 1).

The work was approved by the Ethics Committee of the State Institute of Genetic and Regenerative Medicine of National Academy of Medical Sciences of Ukraine. All the women signed the informed consent form for the study.

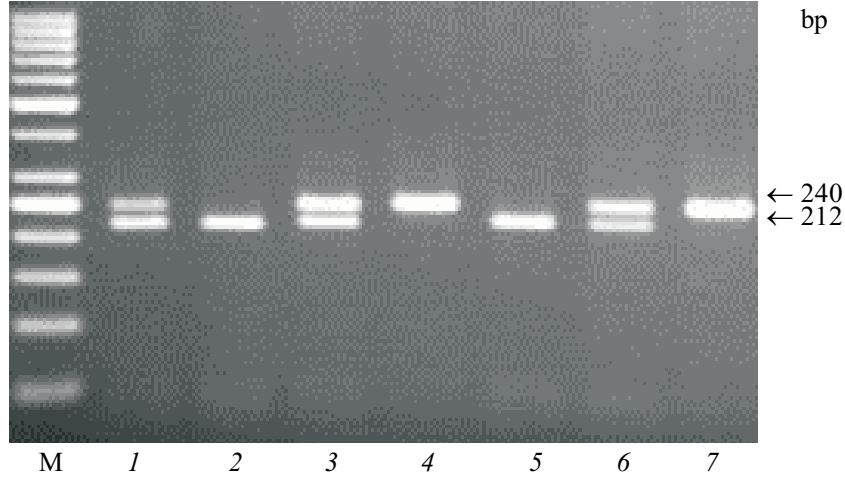

The electrophoregram of the restriction fragment of PON1 gene (C-108T) in $2 \%$ agarose gel: $M$ - DNA marker; samples 2,5 - genotype -108CC; samples 1, 3,6-genotype -108CT; samples 4, 7 genotype -108TT

The peripheral blood leukocytes were used in the molecular and genetic investigation. DNA isolation was conducted using the commercial set «DNA-sorb-B» (the Central Research Institute of Epidemiology, the Ministry of Health Care of the Russian Federation). The genotyping of the polymorphic variant C-108T of PON1 gene was performed using the PCR-RFLP method (the polymerase chain reaction and the restriction fragment length polymorphism), according to the protocol, presented in the work of Grdic et al. [3] and adjusted to our conditions. The fragment of $240 \mathrm{bp}$, obtained during the amplification, was treated with the restriction endonuclease BsrBI (Fermentas, Lithuania). The hydrolytic degradation was performed for the fragment with variant $-108 \mathrm{C}$, whereas the fragment with variant $-108 \mathrm{~T}$ remained undegraded.

The detection of the PCR-RFLP products was conducted in $2 \%$ agarose gel. The visualization of the results was performed in the ultraviolet light after staining with the ethidium bromide solution. The fragment length was analyzed against the DNA marker (Figure).

The statistical processing of the data was conducted on the personal computer using the Statistica 10 and MS Excel 2003 software. The Pearson criterion $\chi^{2}$ and the Pearson criterion $\chi^{2}$ with Yates's correction for the continuity (for less than ten studies) were used to detect reliable differences in the comparison of the frequency of the investigated features for the groups of patients and the control. The efficacy of genotype associations by the polymorphic variant $\mathrm{C}-108 \mathrm{~T}$ of $\mathrm{PON} 1$ gene with the risk of developing diseases was estimated using the value of the odds ratio (OR) in the range of $95 \%$ confidence interval (CI). The differences of $p<0.05$ 
Table 2

The frequency of genotypes by the polymorphic variant $C-108 T$ of PON1 gene in the study groups

\begin{tabular}{c|c|c|c}
\hline \multirow{2}{*}{ Genotype } & \multicolumn{3}{|c}{ Study groups } \\
\cline { 2 - 4 } & $\mathrm{BC}, n(\%)$ & HD, $n(\%)$ & Control, $n(\%)$ \\
\hline$-108 \mathrm{CC}$ & $31(23.66)$ & $28(21.54)^{*}$ & $34(33.33)^{*}$ \\
$-108 \mathrm{CT}$ & $70(53.44)$ & $64(49.23)$ & $48(47.06)$ \\
$-108 \mathrm{TT}$ & $30(22.90)$ & $38(29.23)$ & $20(19.61)$ \\
\hline
\end{tabular}

Note. $* \mathrm{p}<0.05$.

were considered statistically reliable for all the types of analysis.

Results and discussion. The molecular and genetic study allowed determining the genotype frequencies by the polymorphic variant C-108T of PON1 gene in the women study groups (Table 2).

There was a reliable decrease in the frequency of genotype $-108 \mathrm{CC}$ of $P O N 1$ gene in the group of women with HD compared to the control $\left(\chi^{2}=4.06 ; \mathrm{p}<0.05\right.$; $\mathrm{OR}=0.55,95 \%$ CI: 0.31-0.99), which testifies to its protective effect at the development of HD. Therefore, our data confirm the assumption about the protective effect of genotype -108CC of PON1 gene, which is responsible for a high level of the PON1 activity with the risk of developing a cardiovascular pathology.

The similar tendency in the distribution of the genotype frequencies by the polymorphic variant C-108T of PON1 gene was observed for the patients with $\mathrm{BC}$, however the difference was not reliable $(p>0.05)$.

It is known that the HD incidence varies for different age groups of women. For instance, it is considerably higher after 35 and is most common for the women over 54 . On the other hand, a great number of BC cases are diagnosed after 36. It may be explained by the fact that approximately at this age there are involutive changes in the structure of mammary glands resulting in the replacement of the glandular tissue with adipose and/or fibrous tissue. The women after 35 are also notable for rapid progression of fertility impairment, determined by the hormonal changes, i. e. a disbalance, followed by an acute deficiency of female sex hormones, estrogens and progesterone. Taking the abovementioned into consideration, at the next stage the effect of the polymorphic variant $\mathrm{C}-108 \mathrm{~T}$ of $P O N 1$ gene on the risk of developing $\mathrm{BC}$ and $\mathrm{HD}$ was evaluated for three age subgroups of women.

The genotype frequencies for three age subgroups of women with $\mathrm{BC}$ and $\mathrm{HD}$ were compared with the
Table 3

The distribution of genotype frequencies by the polymorphic variant $C-108$ T of PON1 gene in age subgroups of women with BC, HD and the control group

\begin{tabular}{|c|c|c|c|}
\hline \multirow{2}{*}{ Genotype } & \multicolumn{3}{|c|}{ Study groups } \\
\hline & $\mathrm{BC}, n(\%)$ & $\mathrm{HD}, n(\%)$ & Control, $n(\%)$ \\
\hline \multicolumn{4}{|c|}{ 18-35 years } \\
\hline$-108 \mathrm{CC}$ & $11(20.75)$ & $6(27.27)$ & $10(30.30)$ \\
\hline$-108 \mathrm{CT}$ & $27(50.94)$ & $8(36.36)$ & $14(42.42)$ \\
\hline$-108 \mathrm{TT}$ & $15(28.30)$ & $8(36.36)$ & $9(27.27)$ \\
\hline \multicolumn{4}{|c|}{ 36-54 years } \\
\hline$-108 \mathrm{CC}$ & $16(30.77)$ & $14(20.00)$ & $5(21.74)$ \\
\hline$-108 \mathrm{CT}$ & $24(46.15)$ & $38(54.29)$ & $13(56.52)$ \\
\hline$-108 \mathrm{TT}$ & $12(23.08)$ & $18(25.71)$ & $5(21.74)$ \\
\hline \multicolumn{4}{|c|}{ over 54 years } \\
\hline$-108 \mathrm{CC}$ & $4(15.38)^{*}$ & $8(21.05)$ & $19(41.30)^{*}$ \\
\hline$-108 \mathrm{CT}$ & $19(73.08)^{*}$ & $18(47.37)$ & $21(45.65)^{*}$ \\
\hline$-108 \mathrm{TT}$ & $3(11.54)$ & $12(31.58)$ & $6(13.04)$ \\
\hline
\end{tabular}

Note. ${ }^{*} \mathrm{p}<0.05$.

control group. The reliable differences were revealed only for the women over 54 (Table 3).

Compared to the control, the women with $\mathrm{BC}$ of this age subgroup had remarkable increase in the frequency of genotype $-108 \mathrm{CT}$ of PON1 gene $\left(\chi^{2}=4.01 ; \mathrm{p}<0.05\right.$; $\mathrm{OR}=3.23,95 \% \mathrm{CI}: 1.14-9.17)$, which corresponds to a lower level of the PON1 activity. On the other hand, the women over 54 with the genotype -108CC of PON1 gene had almost 4-fold reliably lower risk of developing $\mathrm{BC}\left(\chi^{2}=4.01 ; \mathrm{p}<0.05 ; \mathrm{OR}=0.26,95 \% \mathrm{CI}: 0.08-0.87\right)$. Our results have been indirectly confirmed by the results of the studies, conducted by Stevens et al. and Antognelli et al., when the postmenopausal women had genotype $55 \mathrm{MM}$ by the polymorphic variant $L 55 \mathrm{M}$ of PON1 gene, responsible for a lower level of the PON1 activity, and it was associated with the reliably increasing risk of developing BC $[9,10]$. Saadat $[11]$ also confirmed the fact that the presence of heterozygote $55 \mathrm{LM}$ or homozygote 55MM of PON1 gene was associated with the increasing risk of developing $\mathrm{BC}$.

Why has this regularity been revealed only for older women whereas the paraoxonase 1 activity for adults is known to be constant? The results of recent studies, however, have shown a progressing decrease in the paraoxonase 1 activity for elderly people, which is related 
to the development of the oxidative stress while aging [12]. Thus, our results may be explained by the fact that the women of this age become more sensitive to a decrease in the paraoxonase 1 activity, which, in its turn, leads to a lower level of detoxification of carcinogens and oxidants inducing inflammatory processes.

Conclusions. It is the first study in Ukraine, aimed at the determination of the associations of the polymorphic variant $\mathrm{C}-108 \mathrm{~T}$ of $P O N 1$ gene with the risk of developing $\mathrm{BC}$ and $\mathrm{HD}$ in women. The results of the study give grounds for the assumption that the presence of genotype $-108 \mathrm{CC}$ of PON1 gene in women is associated with an over 1.5 -fold decrease in the risk of developing HD. As for the women over 54, the presence of genotype -108CC of PON1 gene is associated with the almost 4-fold decreased risk of developing $\mathrm{BC}$, whereas the presence of genotype -108CT of PON1 gene is associated with the over 3-fold increased risk of developing BC.

Асоціація генотипів за поліморфним варіантом С-108T гена $P O N 1$ з ризиком розвитку раку молочної залози та гіпертонічної хвороби у жінок

\section{Л. Є. Фіщук}

Резюме

Мета. Проаналізувати вплив поліморфного варіанта С-108T гена PON1 на ризик розвитку раку молочної залози (РМ3) та гіпертонічної хвороби (ГХ) у жінок. Методи. До дослідження залучено 130 жінок з діагнозом ГХ ІІ ступеня з неускладненим перебігом та 131 жінку з діагнозом РМЗ I і II стадій без сериево-судинних ускладнень. До контрольної групи увійшли 102 жінки без сериевосудинної та онкологічної патологій. Для молекулярно-генетичного аналізу використано ДНК, виділену з лейкоцитів периферійноі крові. Генотипування за поліморфним варіантом С-108T гена PON1 проводили із застосуванням методу ПЛР-ПДРФ. Результати. Встановлено, що наявність генотипу -108CС гена PON1 у жінок асоційована зі зниженням ризику розвитку ГХ більш ніж у 1,5 разу. Для жінок, старших 54 років, наявність генотипу -108СС гена PON1 асоиійована із зменшенням ризику розвитку РМЗ майже у 4 рази, а наявність генотипу -108CT гена PON1, навпаки, пов'язана зі зростанням ризику розвитку РМЗ більш ніж у 3 рази. Висновки. Поліморфний варіант C-108T гена PON1 є можливим прогностичним маркером ризику розвитку РМЗ та ГХ у жінок.

Ключові слова: ген, PON1, рак молочної залози, гіпертонічна хвороба.

Ассоциация генотипов полиморфного варианта С-108T гена PON1 с риском развития рака молочной железы и гипертонической болезни у женщин

Л. Е. Фищук

Резюме

Цель. Проанализировать влияние полиморфного варианта С-108T гена PON1 на риск развития рака молочной железы (РМЖ) и ги- пертонической болезни (ГБ) у женщиин. Методы. В исследовании участвовали 130 женщин с диагнозом ГБ ІІ степени с неосложненным течением и 131 женщина с диагнозом РМЖ I и II стадий без сердечно-сосудистых осложнений. Контрольную группу составили 102 женщины без сердечно-сосудистой и онкологической патологий. Для молекулярно-генетического анализа использовали ДНК, выделенную из лейкоцитов периферической крови. Генотипирование по полиморфному варианту C-108T гена PON1 проводили с применением метода ПЦР-ПДРФ. Результаты. Bbявлено, что наличие генотипа -108CC гена PON1 у женщин ассоциировано со снижением риска развития ГБ более чем в 1,5 раза. Для женщин старше 54 лет наличие генотипа -108CС гена PON1 ассоциировано со снижением риска развития РМЖ почти в 4 раза, а наличие генотипа -108CT гена PON1, наоборот, связано с возрастанием риска развития РМЖ более чем в 3 раза. Выводы. Полиморфный вариант C-108T гена PON1 является возможным прогностическим маркером риска развития РМЖ и ГБу женщин.

Ключевые слова: ген, PON1, ракмолочной железы, гипертоническая болезнь.

\section{REFERENCES}

1. Stocks T, Van Hemelrijck M, Manjer J, et al. Blood pressure and risk of cancer incidence and mortality in the Metabolic Syndrome and Cancer Project. Hypertension. 2012;59(4):802-10.

2. Li CI, Daling JR, Tang MT, et al. Use of antihypertensive medications and breast cancer risk among women aged 55 to 74 years. JAMA Intern Med. 2013;173(17): 1629-37.

3. Grdic M, Barisik K, Rumora L, et al. Genetic frequencies of paraoxonase 1 gene polymorphisms in Croatian population. Croat Chem Acta. 2008;81(1):105-11.

4. Polonikov AV, Solodilova MA, Khoroshaya IV, et al. Association study of the two- point mutations of the paraoxonase genes Q192R PON1 and S311C PON2 with predisposition to essential hypertension in Russian inhabitants of Central Chernozem region of Russia. Kurskiy scientifically-practical herald «Persons and his health». 2006;(4):57-61.

5. Yilmaz N. Relationship between paraoxonase and homocysteine: crossroads of oxidative diseases. Arch Med Sci. 2012;8(1): 138-53

6. Bhatnagar V, Liu L, Nievergelt CM, et al. Paraoxonase 1 (PON1) C/T-108 association with longitudinal mean arterial blood pressure. Am J Hypertens. 2012;25(11):1188-94.

7. Voetsch B, Benke KS, Panhuysen CI, Damasceno BP, Loscalzo J. The combined effect of paraoxonase promoter and coding region polymorphisms on the risk of arterial ischemic stroke among young adults. Arch Neurol. 2004;61(3):351-6.

8. Searles Nielsen S, McKean-Cowdin R, Farin FM, et al. Childhood brain tumors, residential insecticide exposure, and pesticide metabolism genes. Environ Health Perspect. 2010;118(1):144-9.

9. Stevens VL, Rodriguez C, Pavluck AL, Thun MJ, Calle EE. Association of polymorphisms in the paraoxonase 1 gene with breast cancer incidence in the CPS-II Nutrition Cohort. Cancer Epidemiol Biomarkers Prev. 2006;15(6):1226-8.

10. Antognelli C, Del Buono C, Ludovini V, et al. CYP17, GSTP1, $P O N 1$ and $G L O 1$ gene polymorphisms as risk factors for breast cancer: an Italian case control study. BMC Cancer. 2009;9:115.

11. Saadat $M$. Paraoxonase 1 genetic polymorphisms and susceptibility to breast cancer: a meta-analysis. Cancer Epidemiol. 2012; 36(2): e101-3.

12. Uzun H, Karter $Y$, Aydin S, et al. Oxidative stress in white coat hypertension; role of paraoxonase. J Hum Hypertens. 2004;18 (7):523-8.

Received 01.04.14 